Dölek, O. (2021). Okuma alışkanlığı ve üstbilişsel yazma stratejileri farkındalığının yazma başarımı üzerindeki etkisi: Bir yapısal eşitlik modellemesi. Ana Dili Eğitimi Dergisi, 9(3), 931-946.

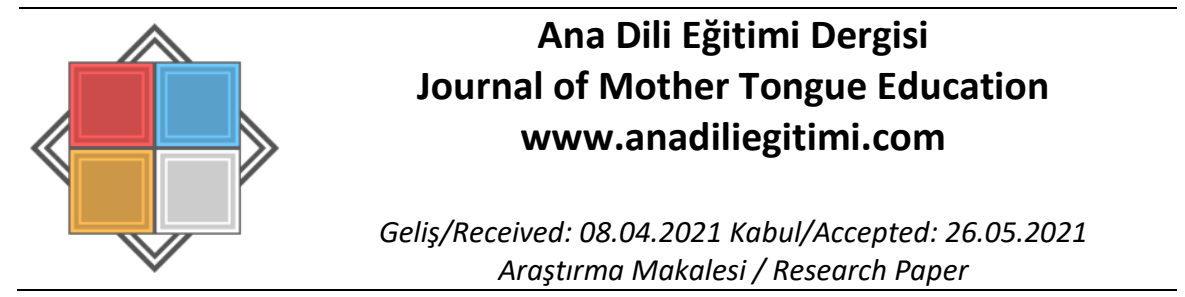

\title{
Okuma Alışkanlığı ve Üstbilişsel Yazma Stratejileri Farkındalığının Yazma Başarımı Üzerindeki Etkisi: Bir Yapısal Eşitlik Modellemesi ${ }^{*}$
}

\author{
Onur DÖLEK $K^{* *}$
}

Öz

Bu çalışma, okuma alışkanlığının ve üstbilişsel yazma stratejileri farkındalığının yazma başarımı üzerinde yordayıcı rolünün olup olmadığını ve bu değişkenlerin açıklayıcılık oranlarının ne düzeyde olduğunu saptamak amacıyla ilişkisel tarama modelinde desenlenmiştir. Araştırma, sekizinci sınıfa devam eden 100 öğrenci ile gerçekleştirilmiştir. Araştırma verilerinin toplanmasında üstbilişsel yazma stratejileri farkındalığı ve ortaokul kitap okuma alışkanlığı ölçekleri ile öğrencilerin oluşturduğu yazılı anlatım metinleri kullanılmıştır. Araştırmadan elde edilen bulgular; yazma başarımının (YB) okuma alışkanlığı (OA) tarafından istatistiksel olarak anlamlı düzeyde yordanmadığı, üstbilişsel yazma stratejileri farkındalık düzeyinin (ÜYSFD) OA tarafından ve YB'nin de ÜYSFD tarafından pozitif yönde istatistiksel olarak anlamlı biçimde yordandığı yönündedir. Açıklayıcılık oranlarına bakıldığında OA'nın YB'ye ait varyansın \%21.2'sini; OA'nın ÜYSFD'ye ait varyansın \%61.9'unu; ÜYSFD'nin YB'ye ait varyansın ise \%34.4'ünü açıklayabildiği görülür. Ayrıca araştırmada $O A^{\prime}$ nın YB üzerindeki dolaylı etkisi istatistiksel olarak anlamlı bulunmuştur. Sonuçlara toplam etki açısından bakıldı̆̆ında, YB'nin en baskın yordayıcısının 0.64 toplam etkiyle ÜYSFD olduğu, bunu 0.50 etkiyle $O A^{\prime} n ı n$ takip ettiği görülmektedir.

Anahtar Kelimeler: Okuma alışkanlı̆̆ı, üstbilişsel yazma stratejileri farkındalığı, yazma başarımı

\section{The Effect of Reading Habits and Metacognitive Writing Strategies Awareness on Writing Success: A Structural Equation Modeling}

\begin{abstract}
This study designed in the relational screening model aims to determine whether reading habits and metacognitive writing strategies awareness have a predictive role on writing success and to examine explanatory levels of these variables. It was conducted with 100 eighth-grade students. Study data were collected using the Metacognitive Writing Strategies Awareness Scale, the Middle School Reading Habits Scale, and written expression texts created by students. Results of the study showed that reading habit (RH) did not statistically significantly predict writing success (WS) and that $\mathrm{RH}$ predicted metacognitive writing strategies awareness (MWSA) and MWSA predicted WS positively and statistically significantly. In examining the explanatory rates, $\mathrm{RH}$ explained $21.2 \%$ of the variance of WS, RH explained $61.9 \%$ of the variance of MWSA, and MWSA explained $34.4 \%$ of the variance of WS. The study also found that the indirect effect of RH on WS was statistically significant. When the results were examined in terms of the total effect, the most dominant predictor of WS was MWSA with 0.64 , followed by RH with 0.50 .
\end{abstract}

Keywords: Reading habits, metacognitive writing strategies awareness, writing success

\footnotetext{
* Bu makale, 4-6 Ekim 2018 tarihleri arasında Ankara Üniversitesinde gerçekleştirilen XI. Uluslararası Türkçenin Eğitimi ve Öğretimi Kurultayında sunulan bildiriden üretilmiştir.

** Dr., MEB, Türkçe Eğitimi, Gaziantep, onur.dolek@hotmail.com, ORCID: orcid.org/0000-0002-8816-2754.
} 


\section{Giriş}

Yazma, düşüncelerin, tasarıların, duyguların, izlenimlerin ve hayallerin bir başkasına aktarılmasında kullanılabilecek çok yönlü araçtır (Dolunay ve Dölek, 2018, s. 575; Graham, 2006). Adler vd. (2001); bireylerin iletişim için harcadıkları zamanın \%45'ini dinlemeye, \%30'unu konuşmaya, $\% 16$ 'sını okumaya ve \%9'unı ise yazmaya ayırdıklarını ileri sürer. Bu oranlara bakıldığında yazmanın temel dil becerileri arasında en az başvurulan eylem olduğu söylenebilir. Buna karşın gelişen teknolojiyle birlikte bireylerin yazmaya duyduğu gereksinim de artmaktadır. Bu gereksinim; başkalarını etkileyebilmenin dışında özellikle sosyal medya ortamlarında doğum günü ve yeni yılı kutlamak, düşünceleri paylaşmak, kurumlarla e-posta aracılığıyla iletişim kurmak gibi durumlarda kendini gösterebilir. Ayrıca Smyth, (1998) duygu, düşünce ve deneyimler ile ilgili yazmanın psikolojik olarak bireye yarar sağlayabileceğini belirtir. Applebee (1984) ise yazmanın öğrenmenin vazgeçilmez bir aracı olduğunu, bilgileri toplamak ve korumak için kullanılabileceğini vurgular. Yaşamın her alanında yazmaya duyulan gereksinim yazmanın önemini de belirginleştirmektedir. Bu nedenle öğrencilerin eğitim sürecinde yazma becerisine ilişkin kazanımları elde ederek nitelikli birer yazar durumuna gelebilmeleri gerekir.

Alanyazın incelendiğinde yazma becerisinin geliştirilmesine yönelik çeşitli yöntem, teknik ve stratejilerin etkililiğinin sınandığı (Alberth, 2018; Bayat, 2014; Dölek ve Hamzadayı, 2016; Rao, 2007) ve yazmanın duyuşsal nitelikler açısından incelendiği (Arıcı ve Dölek, 2020; Huerta vd., 2017; Özonat, 2015) çalışmalar olduğu görülür. Buna karşın ortaokul öğrencileri arasında yazma başarımının istenen düzeyde olmadığı bilinmektedir (Dölek ve Hamzadayı, 2018). Bu nedenle araştırmada yöntem, teknik, strateji ve duyuşsal niteliklerin dışında yazma becerisi üzerinde etkili olabileceği öngörülen okuma alışkanlığı ve üstbilişsel yazma stratejileri farkındalığına odaklanılmıştır. Bu amaç doğrultusunda öncelikle okuma alışkanlığı ve üstbilişsel yazma stratejileri farkındalı̆̆ı kavramları açıklanmıştır.

\section{Okuma Alışkanlığı}

Okuma, yazılı bir metni anlamak ve o metinden gerekli bilgileri elde etmektir. Birey, farklı metinler üzerinde farklı okuma stratejileri uygulayarak zevk almak, bir şeyi araştırmak, bir sorunu çözmek ve bilgilenmek amacıyla da okuma yapabilir (Grellet, 1981, s. 3-4). Okumak, sözcük bilgisini artırmada, okuduğunu anlamada ve yazım becerilerini geliştirmede etkin bir rol üstlenir (Pressley, 2002). Okuma sürecinde yazılı bir metni görme, kodlama ve çözümleme aşamaları izlenir.

Alışkanlık bireyin hayatında etkili ve belirleyici rolde sürekli var olan; fiziksel, duygusal, zihinsel ve toplumsal tutumuna yön veren; kişiliğini ve karakterini oluşturan davranıştır ve olumlu davranış kazandırma yönüyle eğitim biliminde önemli rol oynamaktadır (Orhan, 2017). Kısaca alışkanlık bir davranışın düzenli ve sürekli olarak sergilenmesidir ve bunun birey üzerinde psikolojik etkileri vardır. Birey, kendisini rahatlattığını veya kendisine yarar sağlayacağını düşündüğü ve daha önemlisi zevk aldığı bir davranışı alışkanlık haline getirebilir. Bu bağlamda okuma alışkanlığı için bireyin okumayı bir zevk ve gereksinim olarak görmesi ve hayat boyu devamlı ve düzenli biçimde gerçekleştirmesi tanımı yapılabilir (Gönen vd., 2004, s. 8). Okuma alışkanlığı, bireyi bilişsel ve duyuşsal yönlerden sürekli olarak geliştirir ve topluma yararlı bireyler yetiştirme konusunda etkin bir rol oynar. Öte yandan Bashir ve Mattoo (2012) okuma alışkanlığının öğrencilerin akademik başarıları üzerinde de etkili olduğunu belirtir.

Modern eğitim felsefesinde öğrenme, hayat boyu devam eden bir süreç olarak görülmektedir. Bu süreçte çeşitli alanlara ilişkin bilgi sahibi olabilmek okuma alışkanlığı edinme ile olanaklıdır (Arslan vd., 2009). Günlük yaşamı daha anlamlı hale getirmek, gelişen teknolojiye ayak uydurmak ve mesleki gelişimini sürdürmek gibi birçok nedenden dolayı bireyler artarak okumalı ve bunu da alışkanlık haline getirmelidir. Alanyazına bakıldığında farklı kademelerdeki öğrencilerin okuma alışkanlıklarına ilişkin çalışmalar (Yılmaz, 2006; Balcı vd., 2012) olduğu görülmektedir. Bu kademelerdeki okuma alışkanlıkları arasında farklılıklar bulunmasına karşın çalışmalardan çıkarılabilecek ortak sonuç, ülkemizde okuma alışkanlığının yeterli düzeyde olmadığıdır. Okumanın alışkanlık haline gelebilmesi için ailelerin okuma bilincine sahip olması ve okumaya zaman ayırmaları, eğitim programlarının bireylerde okuma alışkanlığını kazandırabilecek biçimde tasarlanması, öğrencilerin doğru zamanda uygun kitap ile 
buluşturulması, okuma güdüsünün artırılması, sınıf içi etkinliklerin düzenlenmesi, eve kitap, gazete ve dergi alınması gerekir (Bamberger, 1990; Özer ve Doğan, 2013).

\section{Üstbilişsel Yazma Stratejileri ve Farkındalığı}

Üstbiliş, bireyin kendi biliş sistemine, yapısına ve çalışmasına ilişkin bilgisidir (Doğan, 2013). Üstbiliş bireysel nitelik taşır. Üstbilişsel farkındalıkla birey dikkat, algı, tekrar, kodlama ve geri getirme gibi bilişsel süreçleri kontrol eder ve yönetir (Yüksel, 2013, s. 61). Üstbilişsel bilgi, bilişsel işlemlerin seyrini ve sonucunu hangi etmenlerin ya da değişkenlerin nasıl etkileyebileceği konusundaki bilgi ve düşünceleri kapsar. Üstbiliş; sözlü iletişim, ikna etme, okuduğunu ve dinlediğini anlama, yazma, dil edinimi, dikkat, bellek, problem çözme, sosyal biliş ve özdenetimli öğrenme gibi alanlarda önemli rol oynar (Flavell, 1979). Üstbilişsel bilgi ve uygun strateji kullanımı öğrenme becerilerinin önemli belirleyicileri arasında gösterilebilir. Çünkü üstbilişsel stratejilere veya bilgiye sahip öğrenciler, öğrenme sürecinde etkin rol üstlenerek süreci kontrol etme yetisi gösterirler (Chari vd., 2010). Üstbilişsel işlemler zihinsel etkinlikleri düzenler, aynı zamanda diğer bilişsel işlemlerin etkinliğini denetleyerek onlara yön verir ve belirli bir amaca ulaşmak için zihinsel etkinliklerin eşgüdümünü sağlar (Smith ve Kosslyn, 2017, s. 281). Bu bağlamda üstbilişsel öğrenme, bireyin kendi yeterlikleri veya eksikleri doğrultusunda öğrenme sürecinde etkin bir biçimde yer alarak ve özdenetim sağlayarak uygun teknik ve yöntemleri işe koştuğu bilişsel etkinlik biçiminde ifade edilebilir.

Strateji, içinde planlama, bir hedefe doğru hareket etme ve yönetme gibi eylemleri barındıran bir kavramdır. Bir başka deyişle strateji, bir konuda başarıya ulaşmak için planlı ve bilinçli bir biçimde hareket etme anlamına gelir (Oxford, 1990, s. 7-8). Yazma stratejileri ise; yazının nitelikli olabilmesi için yazma öncesi, yazma sırası ve yazma sonrasında yazar tarafından işe koşulan teknik ve yöntemleri kapsayan bilişsel etkinliklerdir. Kısaca, yazma stratejileri yazarların yazılarını geliştirmek için kullandıkları özel işlemler ve tekniklerdir (Bai, 2015). Westwood'a $(2008$, s. 72 ) ve Pour-Mohammadi, Abidin ve Fong'a (2012) göre strateji geliştirmek öğrencilerin yazma becerilerini geliştirmesinde oldukça etkilidir. Aynı zamanda stratejiler, yazma sürecinde karşılaşılan sorunların çözülmesine yardım eder ve bu süreçte elde edilen girdilerin başka bir beceri alanına aktarılmasını sağlar (De Silva, 2015). Benzer bir biçimde Chalk vd. (2005) yapmış oldukları çalışmada, öğrencilerin yazıyı planlama ve gözden geçirme sürecinde etkili stratejileri işe koşmalarının ve gelişen özdüzenleme becerilerinin nitelikli ürünler ortaya koymalarını sağladığını belirtmişlerdir.

Alanyazına bakıldığında farklı yazma stratejileri olmasına karşın hepsi, ortak bir amaca ve benzer özelliklere sahip olma eğilimindedir. Bu stratejiler, öğrencilerin yazmaya başlamadan önce üretici bir biçimde düşünmelerine, düşüncelerini mantıklı bir biçimde sıraya koymasına, düşüncelerini ayrıntılandırmasına ve oluşturulan metni gözden geçirmesine yardımcı olur (Westwood, 2008, s. 75). Yazma stratejileri arasında sözlük kullanma, stratejiyi gözden geçirme, beyin fırtınası, ön izleme ve metnin yapısını planlama gibi bilişsel etkinlikler yer alır (De Silva, 2015). Monet (2003) yazma sürecinde düşünce üretme, düşünceleri geliştirme ve düzenleme, gözden geçirme ve düzeltme olarak ele aldığı yazma sürecinde hızlı yazma, bağlamı düzenleme, içerik ekleme, haritalama, ana düşünceyi destekleme, yeni ayrıntılar ekleme, düşünceleri tekrar düzenleme, düzenleyici sorular sorma, akran denetimine başvurma ve amaç belirleme gibi stratejilere başvurulabileceğini belirtir.

Bu bilgiler doğrultusunda üstbilişsel yazma stratejileri farkındalığı; bireyin yazma öncesi, sırası ve sonrası aşamalarında işe koşabileceği stratejilerin işlevinin ve yazma stratejilerine ilişkin kendi bilişsel becerilerinin farkında olması biçiminde tanımlanabilir. Bilişsel farkındalık becerilerine sahip olan bir kişi; öncelikle öğreneceği konuya odaklanır. Böylece birey, bilişsel farkındalıkla bilgisini ve düşüncesini denetleyebilmeyi sağlar. Sonra neyi, nerede ve nasıl yapacağını planlar. Planın işleyip işlemediğini denetler. Planın aksayan yönleri için çözüm üretmeye çalışır (Gelen, 2003). Üstbilişsel yazma stratejileri farkındalık düzeyi yüksek olan bireyden de kendisini ve yazma sürecini denetlemesi beklenir. Kaya ve Ateş (2016) üstbilişsel beceriye sahip olan bireylerin yazma sürecinde kendilerine metnin türü, yazmak için gerekli süre, yazının planı ve metnin gözden geçirilmesine ilişkin sorular sorması gerektiğini belirtir. Yazma süreci sonunda bireyin nitelikli bir ürün elde edebilmesinde bu soruların önemli bir yeri olduğu söylenebilir. Nitekim bu sorular, yazma stratejilerinin kullanımına ilişkin bireyde üstbilişsel farkındalık oluşmasına katkı sağlar. 


\section{Değişkenler Arası Kavramsal iliş̧ki}

Okuma sürecinde, metni anlamlandırmak için kullanılan çeşitli stratejiler, bireyin bilişsel yapısının gelişmesine katkı sunar. Öte yandan okuma, sözcük bilgisini artırmada (Leung, 2002) ve metnin dil bilgisel yapısını çözümlemede de önemli rol oynar. Benzer bir biçimde Harmer (2007), okumanın bir dil modeli olduğundan ve okuma metinlerinin cümle, paragraf veya metin oluşturmak için bireye sözcük bilgisi, noktalama işaretlerinin doğru kullanımı ve dil bilgisi gibi çeşitli beceriler kazandırabileceğinden söz eder. Okumanın bireye sağladığı bilgi, deneyim ve yeni anlamlar nedeniyle yazma sürecinin en önemli bileşenlerinden biri olduğu kabul edilir (Kartal, 2017). Bu bağlamda okuma sürecinde elde edilen olaylara farklı açılardan yaklaşabilme, eleştirel düşünebilme, dil bilgisel bütünlük sağlayabilme gibi becerilerin ve artan sözcük bilgisinin yazma sürecine yansıması kaçınılmazdır. Nitekim Eroğlu (2013) ve Akkaya ve İşçi (2018) okuma alışkanlığı ile yazma becerileri arasında olumlu yönde anlamlı bir ilişki olduğunu bulgulamışlardır. Baş ve Şahin (2012) ve Akın (2016) ise yapmış oldukları çalışmada okuma alışkanlıkları ile yazma eğilimleri arasında olumlu yönde anlamlı bir ilişki saptamışlardır.

Öte yandan Kana (2014) tarafından yapılan bir çalışmada okuma alışkanlığı ile üstbilişsel okuma stratejileri arasında anlamlı bir ilişkiye ulaşıımıştır. Benzer bir ilişkinin okuma alışkanlığı ile üstbilişsel yazma stratejileri farkındalığı arasında da olduğu görülmektedir (Aydın ve Bağcı Ayrancı, 2018). Ayrıca alanyazına bakıldığında öğrencilerin üstbilişsel farkındalık düzeylerini (Gürefe, 2015; Kapucu ve Öküz, 2015); öğrencilerin üstbilişsel okuma stratejileri farkındalık düzeylerini (Aybek ve Aslan, 2016; Kuruyer ve Özsoy, 2016; Mokhtari ve Reichard, 2002); üstbilişsel becerilerin akademik başarıya etkisini (Owo ve Ikwut, 2015; Zulkiply, 2009); üstbilişsel farkındalığın okuma becerileri üzerindeki etkisini (Çakıroğlu, 2007; Gelen, 2003) ve yazma stratejileri kullanımının yazma becerileri üzerindeki etkisini (Bai, 2015; Belet ve Yaşar, 2007; Conti, 2004; Topuzkanamış, 2014a) inceleyen çalışmalar olduğu görülmektedir. Buna karşın yapısal eşitlik modellemesi kapsamında okuma alışkanlığı ve üstbilişsel yazma stratejileri farkındalığının yazma becerileri üzerindeki yordayıcı rolüne ilişkin bir çalışmaya rastlanmamıştır. Bu doğrultuda okuma alışkanlığı ve üstbilişsel yazma stratejileri farkındalıklarının yazma becerileri üzerindeki etkisini belirlemenin yazma sürecindeki farkındalığın artırılması ve uygulayıcılara yol gösterici olması bakımından önemli olabileceği düşünülmektedir. Illgili alanyazın taranarak ortaya konan okuma alışkanlığı ve üstbilişsel yazma stratejileri farkındalığının yazma becerileri üzerindeki etkisinin incelendiği bu çalışmaya yönelik oluşturulan model Şekil 1'de gösterilmiştir:

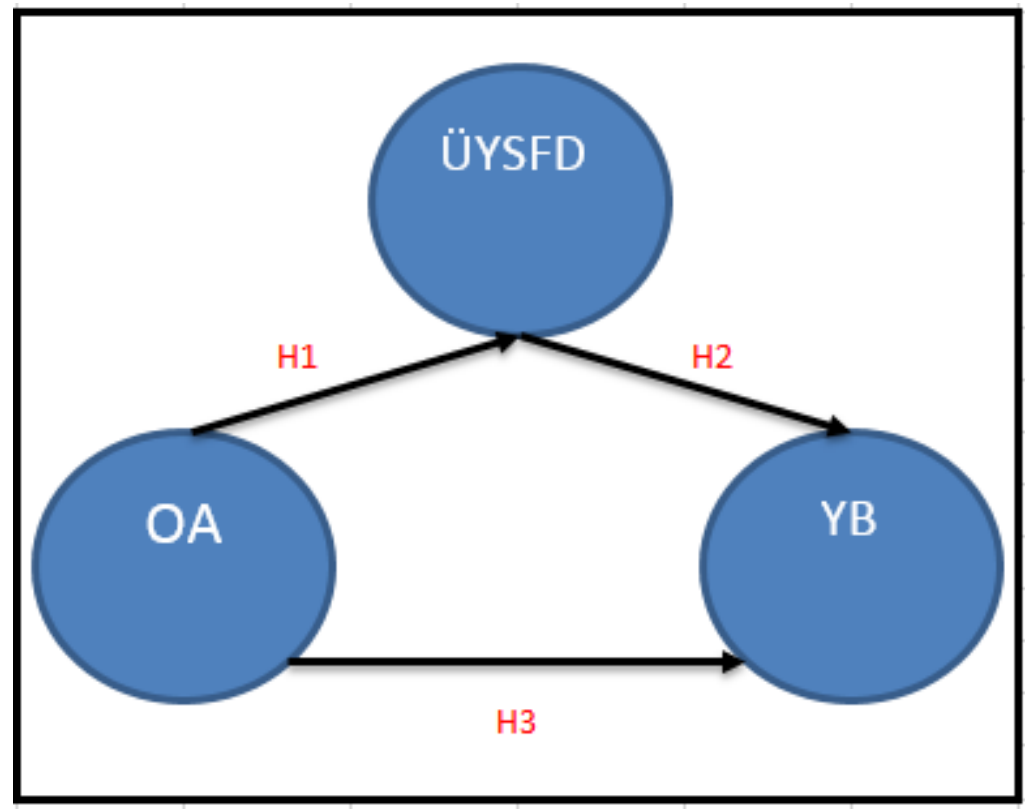

Şekil 1. Araştırma Modeli

(Not: OA: Okuma alışkanlı̆̆ı; ÜYSFD: Üstbilişsel yazma stratejileri farkındalık düzeyi; YB: Yazma başarımı) 
Yukarıda verilen araştırma modeli kapsamında araştırmanın amacı, okuma alışkanlığının ve üstbilişsel yazma stratejileri farkındalık düzeyinin yazma başarımına etkisinin varlığını belirlemek, bu değişkenlerin birbirlerini nasıl yordadıklarını ve açıklama oranlarının ne düzeyde olduğunu saptamaktır. Bu amaç doğrultusunda önerilen araştırma hipotezleri aşağıda verilmiştir:

H1: Okuma alışkanlığı, üstbilişsel yazma stratejisi farkındalık düzeyini olumlu yönde anlamlı düzeyde yordamaktadır.

H2: Üstbilişsel yazma stratejisi farkındalık düzeyi, yazma başarımını olumlu yönde anlamlı düzeyde yordamaktadır.

H3: Okuma alışkanlığı, yazma başarımını olumlu yönde anlamlı düzeyde yordamaktadır.

\section{Araştırmanın Modeli}

\section{Yöntem}

Bu çalışma, ortaokul öğrencilerinin kitap okuma alışkanlıkları ve üstbilişsel yazma stratejileri farkındalık düzeylerinin yazma başarımları üzerindeki etki düzeyini ve bu değişkenlerin birbirlerini nasıl yordadıklarını saptamak amacıyla ilişkisel tarama modelinde desenlenmiştir. Tarama desenleri, bir evren içinden belirlenen bir örneklem üzerinde yürütülen çalışmalar aracalığıyla evren genelindeki eğilim, tutum ve görüşlerin nicel olarak betimlenmesine katkı sunar (Creswell, 2016, s. 155). iliş̧kisel tarama modeli ise, iki ya da daha çok değişken arasındaki ilişkinin değişkenlere müdahale edilmeden incelendiği çalışmalardır (Büyüköztürk vd., 2016, s. 185). Illgili kuramsal çerçeve kapsamında oluşturulan modele ilişkin okuma alışkanlığı, üstbilişsel yazma stratejileri farkındalığı ve yazma başarımı değişkenleri arasındaki ilişkiler Yapısal Eşitlik Modellemesi (YEM) yoluyla incelenmiştir. YEM, birden fazla değişken arasındaki ilişkilere yönelik kurulan model neticesinde çok yönlü ve karmaşık bir araştırma problemini tek bir süreçte inceleyen ve kuram geliştirmeye dayanan istatistiki bir analiz yöntemidir (Anderson ve Gerbing, 1988; Byrne, 2010; akt. Baki, 2017).

\section{Araştırma grubu}

Alanyazın incelendiğinde ortaokul 8. sınıf öğrencilerinin yazma başarımlarının istenen düzeyde olmadığını gösteren çalışmalar (Demir, 2013; Dölek ve Hamzadayı; 2018) olduğu görülmektedir. Öte yandan 8. sınıf öğrencilerinin yaşları 13-14 arasında değişmektedir. Bu dönem Piaget'in bilişsel gelişim evresinin soyut işlemler dönemine denk gelmektedir. Bu dönemde bireyler, soyut düşünebilme ve düşünceleri hakkında düşünebilme (üstbiliş) becerilerini kazanır. Karşılaşılan sorunlara gerçekçi ve sistematik çözümler getirmeyi öğrenir (Ak Mert, 2007; Özdemir vd., 2012). Bu becerilerin yazma sürecinde de edinilmesi gerekir. 8. sınıf düzeyinin bu beceriler için kritik evre olduğu söylenebilir. Ayrıca 8. sınıf düzeyinde bu değişkenler arasındaki ilişkiyi birlikte inceleyen bir araştırmaya rastlanmamıştır. Bu nedenle okuma alışkanlığı ve üstbilişsel yazma stratejileri farkındalığının yazma başarımı üzerindeki etkisini incelemenin alanyazına katkı sağlayacağı düşünülmektedir. Bu bağlamda araştırmanın çalışma grubunu Gaziantep ilindeki bir ortaokulda 8. sınıfa devam eden 100 öğrenci oluşturmaktadır. Çalışma grubunda yer alan öğrencilerin \%51 ( $n=51)^{\prime}$ i erkek, \%49 ( $\left.n=49\right)^{\prime}$ u kızdır.

\section{Veri Toplama Araçları}

Araştırma verilerinin toplanmasında Üstbilişsel Yazma Stratejileri Farkındalığı Ölçeği, Ortaokul Kitap Okuma Alışkanlığı Ölçeği, Yazılı anlatım kâğıtları ve bu kâğıtların değerlendirmesinde Kompozisyon Değerlendirme Ölçeği kullanılmıştır.

Üstbilişsel Yazma Stratejileri Farkındalık Ölçeği: Bu ölçek, Aydın vd. (2017) tarafından ortaokul öğrencilerinin üstbilişsel yazma stratejilerine ilişkin farkındalıklarını belirlemek için geliştirilmiştir. Ölçekte $5^{\prime}$ li likert tipinde 40 madde yer almaktadır.

Kitap Okuma Alışkanlığı Ölçeği: Tok, Küçük ve Kırmacı (2015) tarafından geliştirilen bu ölçekle ortaokul öğrencilerinin kitap okuma alışkanlıklarının belirlenmesi amaçlanmıştır. Ölçekte 5 'li likert tipinde 15 madde yer almaktadır.

Kompozisyon Değerlendirme Ölçeği: Öğrencilerden elde edilen yazılı anlatım kâğıtlarının değerlendirilmesinde "Kompozisyon Değerlendirme Ölçeği" kullanılmıştır. Yazılı anlatım kâğıtları, üç 
alan uzmanı tarafından bu ölçeğe bağlı kalınarak değerlendirilmiştir. "Kompozisyon Değerlendirme Ölçeği" Konedralı ve Özder (2007) tarafından yazılı metinleri değerlendirmek amacıyla geliştirilmiştir. Ölçekte $5^{\prime}$ li likert tipinde 25 madde yer almaktadır.

\section{Verilerin Toplanması}

Araştırma verileri, 2017-2018 eğitim öğretim yılı içerisinde Gaziantep'te bulunan bir ortaokulun 8. sınıfına devam eden öğrencilerden toplanmıştır. Öğrenciler gönüllü olarak çalışmaya katılmışlardır. Verileri toplamaya başlamadan önce ölçeğe ve uygulamaya yönelik ilgili kurum ve araştırmacılardan gerekli izinler alınmıştır. Öğrencilere çalışma ve uygulama ile ilgili kısa bilgiler verilmiştir. Daha sonra onlardan üstbilişsel yazma stratejileri farkındalık ölçeği ile ortaokul kitap okuma alışkanlığı ölçeğini doldurmaları istenmiştir. Ölçeklerin doldurulmasına yönelik gerekli süre verilmiştir. Ölçeklerin doldurulmasından bir hafta sonra "Radyo televizyon, gazete gibi kitle iletişim araçlarının yararları ve zararları" konusunda onlardan bir metin yazmaları istenmiştir. Yazma süresiyle ilgili bir kısıtlamanın olmadığı ve adların gizli tutulacağı öğrencilere önceden bildirilmiştir.

\section{Verilerin Analizi}

İstatistiksel analizler için NCSS (Number Cruncher Statistical System) 2007 (Kaysville, Utah, USA) programı; çalışma verilerinin değerlendirilmesi için ise tanımlayıcı istatistiksel yöntemler kullanılmıştır. Verilerin normal dağıım gösterip göstermedikleri Shapiro-Wilk testi ve grafiksel incelemeler aracılığıyla incelenmiştir. Nicel değişkenler arası ilişkilerin belirlenmesinde Pearson korelasyon analizinden yararlanılmıştır. Üstbilişsel Yazma Stratejisi Farkındalık Ölçeğinin yapı geçerliliği Açıklayıcı Faktör Analizi ile test edilmiştir. Ölçeklerin iç tutarlılık düzeylerinin belirlenmesinde Cronbach alfa katsayısından yararlanılmıştır. Okuma alışkanlığının, yazma becerileri puanı üzerine olan etkisinde, üstbilişsel yazma stratejisi farkındalık düzeyinin aracı etkisi, lineer regresyon modelleri ve YEM (Yapısal Eşitlik Modelleri) ile değerlendirilmiş ve istatistiksel anlamlılık $p<0.05$ olarak kabul edilmiştir.

\section{Geçerlik ve Güvenirlik}

Üstbilişsel yazma stratejileri farkındalık ölçeğinin bu araştırma için güvenirlik ve geçerlik çalışması tekrar yapılmıştır. Açıklayıcı faktör analizinden önce Kaiser-Meyer-Olkin (KMO) ve Bartlett's Küresellik Testi yapılmıştır. Gerçekleştirilen analiz sonucunda KMO değerinin 0.843 olduğu ve Bartlett testinin istatistiksel olarak anlamlı olduğu saptanmıştır $(p<0.001)$. Bu durum verilerin faktör analizine uygunluğunu doğrulamaktadır. Ölçeğin faktör yapısını belirleyebilmek için temel bileşenler analizi kullanılmıştır. İlk değerlendirme sonucunda 23 numaralı maddenin faktör yükünün 0.300 düzeyinin altında (0.286) olduğu gözlenmiştir ve bu nedenle bu madde ölçekten çıkarılmıştır. Kalan 39 madde ile gerçekleştirilen analiz sonucunda ise KMO değerinin 0.853 olduğu ve Bartlett testinin istatistiksel olarak anlamlı olduğu saptanmıştır $(p<0.001)$. Açıklayıcı faktör analizinde, tek faktörlü yapıya yönelik faktör yük değerleri 0.376-0.682 arasında değişmektedir. ÜYSFÖ iç tutarlılığının ( $\alpha$ ) 0.941 olduğu bulgulanmıştır.

Okuma alışkanlığı ölçeğinin bu araştırma için tekrar iç tutarlıık analizi yapılmıştır. Okuma alışkanlığı ölçeği 3 faktörlü bir yapıya sahiptir. Buna göre birinci faktör 2, 5, 7, 9, 12, 14 ve 15 numaralı maddelerden, ikinci faktör 4, 6, 8, 11 ve 13 numaralı maddelerden, üçüncü faktör ise 1 , 3 ve 10 numaralı maddelerden oluşmaktadır. Ölçeğin alt boyutlarının Cronbach's Alpha katsayıları sırasıyla ,862; ,778 ve ,635 olarak bulgulanmıştır.

Kompozisyon değerlendirme ölçeği "Buluş, Planlama ve Anlatım" alt boyutlarından oluşmaktadır. Ölçeğin Cronbach's Alpha katsayısı .80'dir. Ölçeğin alt boyutlarının Cronbach's Alpha katsayıları sırasıyla ,86; ,80 ve, 79 olarak saptanmıştır.

\section{Araştırma ve Yayın Etiği}

Bu çalışmada "Yükseköğretim Kurumları Bilimsel Araştırma ve Yayın Etiği Yönergesi" kapsamında uyulması belirtilen tüm kurallara uyulmuştur. Yönergenin ikinci bölümü olan "Bilimsel Araştırma ve Yayın Etiğine Aykırı Eylemler" başlığı altında belirtilen eylemlerden hiçbiri gerçekleştirilmemiş̧ir. 
Okuma Alışkanlığı ve Üstbilişsel Yazma Stratejileri Farkındalığının Yazma Başarımı Üzerindeki Etkisi: Bir Yapısal Eşitlik Modellemesi

\section{Etik Kurul İzi}

Kurul adı = Bolu Abant İzzet Baysal Üniversitesi Sosyal Bilimlerde İnsan Araştırmaları Etik Kurulu Karar tarihi $=01.02 .2021$

Belge sayı numarası $=2021 / 08,2021 / 01$

\section{Bulgular}

Araştırmadan elde edilen bulgular iki bölümde sunulmuştur. Birinci bölümde model değişkenlerine ilişkin betimsel istatistiklere ve bu değişkenler arasındaki ilişkilerin Pearson korelasyon analizi sonucunda elde edilen bulgulara; ikinci bölümde ise yapısal eşitlik modellemesi doğrultusunda oluşturulan hipotezlere ilişsin bulgulara yer verilmiştir.

\section{Model Değişkenlerine İlişkin Betimsel İstatistikler ve Bu Değişkenlerin Pearson Korelasyon Analizi}

Araştırma modelinde yer alan değişkenlere ilişkin betimsel istatistikler ve bu değişkenler arası ilişki düzeyleri Tablo 1'de verilmiştir:

Tablo 1.

Değişkenler Arası Betimsel Istatistikler ve ilişsi Düzeyleri

\begin{tabular}{llll}
\hline & OA & ÜYSFD & YB \\
\hline Korelasyon $(r)$ & & & \\
OA & 1 & & \\
ÜYSFD & $0.789^{* * *}$ & 1 & \\
YB & $0.469^{* * *}$ & $0.592^{* * *}$ & 1 \\
Ortalama & 44.63 & 123.87 & 72.65 \\
SS & 12.00 & 25.66 & 16.61 \\
Çarpıklık & -0.125 & -0.110 & 0.102 \\
Basıklık & -0.724 & -0.490 & -0.533 \\
n & 100 & 100 & 100 \\
\hline
\end{tabular}

$* * * p<0.001$

(Not: OA: Okuma Alışkanlığı, ÜYSFD: Üstbilişsel yazma stratejileri farkındalık düzeyi, YB: Yazma Başarımı)

Tablo 1'e bakıldığında OA ile ÜYSFD arasında pozitif yönde, 0.789; OA ile YB arasında pozitif yönde, 0.469 ve ÜYSFD ile YB arasında ise pozitif yönde, 0.592 düzeyinde ve istatistiksel olarak anlamlı ilişki olduğu bulgulanmıştır $(p<0.001)$.

\section{Araştırmanın Hipotezlerine ilişkin Bulgular}

Aracı etki analizinin ön koşullarını sınamak amacıyla üç farklı model oluşturulmuştur.

Tablo 2.

Aracı Etki Analizinin Ön Koşullarını Sınamak Amacıyla Oluşturulan Modeller

\begin{tabular}{lllllll}
\hline Model & Tahmin edilen & $\begin{array}{l}\text { Tahmin } \\
\text { eden }\end{array}$ & R2adj & Beta & Std.beta & $\mathrm{p}$ \\
\hline 1 & YB & OA & 0.212 & 0.649 & 0.469 & $<0.001^{* *}$ \\
2 & ÜYSFD & OA & 0.619 & 1.687 & 0.789 & $<0.001^{* *}$ \\
3 & YB & ÜYSFD & 0.344 & 0.383 & 0.592 & $<0.001^{* *}$ \\
\hline
\end{tabular}

Illk modelde YB tahmin edilen, $O A$ ise tahmin eden değişken olarak yer alınmıştır. Elde edilen modelin istatistiksel olarak anlamlı olduğu, $O A^{\prime} n ı n ~ Y B^{\prime} y e$ ait varyansın \%21.2'sini açıklayabildiği 
saptanmıştır (F:27.685, p<0.001, R2adj:0.212). OA'da gerçekleşecek bir birimlik artışın YB'yi 0.649 birim artıracağı saptanmıştır [ $\beta$ (\%95 GA): 0.649 (0.404, 0.894), p<0.001].

ikinci modelde ÜYSFD tahmin edilen, OA ise tahmin eden değişken olarak yer alınmıştır. Elde edilen modelin istatistiksel olarak anlamlı olduğu, OA'nın ÜYSFD'ye ait varyansın \%61.9'unu açıklayabildiği saptanmıştır (F:162.132, p<0.001, R2adj:0.619). OA'da gerçekleşecek bir birimlik artışın ÜYSFD'yi 1.687 birim artıracağı saptanmıştır [ $\beta$ (\%95 GA): 1.687 (1.424, 1.950), $p<0.001]$.

Üçüncü modelde YB tahmin edilen, ÜYSFD ise tahmin eden değişken olarak yer alınmıştır. Elde edilen modelin istatistiksel olarak anlamlı olduğu, ÜYSFD'nin YB'ye ait varyansın \%34,4'ünü açıklayabildiği saptanmıştır ( $F: 52.906, p<0.001$, R2adj:0.344). ÜYSFD'de gerçekleşecek bir birimlik artışın YB'yi 0.383 birim artıracağı saptanmıştır [ $\beta$ (\%95 GA): $0.383(0.279,0.488), p<0.001]$.

Okuma alışkanlığı ve üstbilişsel yazma stratejileri farkındalık düzeyinin yazma becerileri üzerindeki etkisini saptamak için kurulan yapısal modele ilişkin sonuçlar Şekil 2'de sunulmuştur:

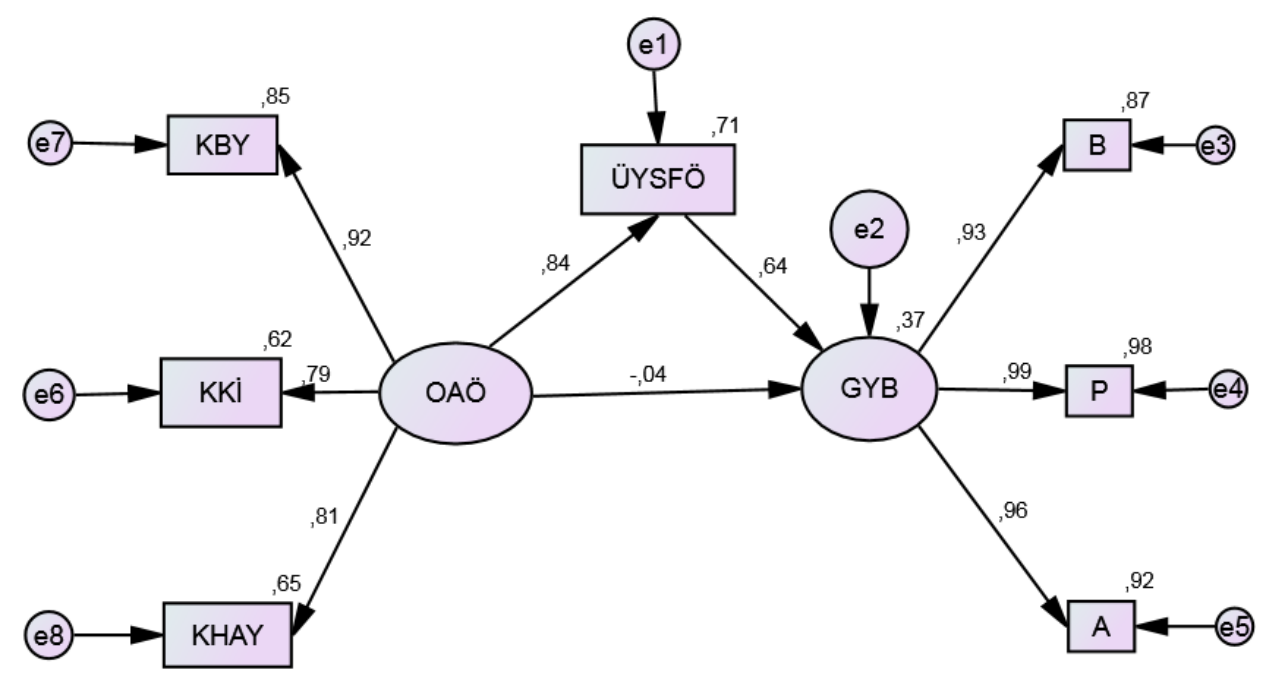

Şekil 2. Okuma Alışkanlığı ve Üstbilişsel Yazma Stratejileri Farkındalığının Yazma Başarımı Üzerindeki Etkisi

(Not: KBY: Kitapların Becerilere Yansıması, KKi: Kitapla Kurulan İlişki, KHAY: Kitaptan Hareketle Anlatıma Yönelme, OAÖ: Okuma Alışkanlığı Ölçeği, ÜYSFÖ: Üstbilişsel yazma stratejileri farkındalık Ölçeği, GYB: Genel Yazma Başarımı, B: Buluş alt boyutu, P: Planlama alt boyutu, A: Anlatım alt boyutu).

Okuma alışkanlığı ve üstbilişsel yazma stratejileri farkındalık düzeyinin yazma becerileri üzerindeki etkisini belirlemek içim kurulan yapısal eşitlik modellemesi ile ulaşılan uyum iyiliği değerlerinin " $\chi 2 / \mathrm{df}=1.288$, GFI: 0.958, CFI:0.995, TLI:0.992, NFI:0.979, IFI:0.995, RMSEA:0.054, SRMR:0.028" olduğu saptanmıştır. Yapısal modelin testi sonucunda OAÖ gizil değişkeninin faktör yüklerinin $0.92,0.81$ ve 0.79 olduğu, GYB gizil değişkeninin faktör yüklerinin ise $0.93,0.99$ ve 0.96 olduğu saptanmıştır.

Tablo 3.

OA ve ÜYSFD'nin GYB Üzerindeki Etkisine Iliş̧kin Standardize Edilmiş Regresyon Ağırlığı Sonuçları

\begin{tabular}{llll}
\hline Yol & Beta & Std.beta & $\mathrm{p}$ \\
\hline OA $\rightarrow$ ÜYSFD & 10.290 & 0.844 & $<0.001^{* *}$ \\
OA $\rightarrow$ YB & -0.079 & -0.044 & 0.811 \\
ÜYSFD $\rightarrow$ YB & 0.094 & 0.644 & $<0.001^{* *}$ \\
\hline
\end{tabular}


Tablo 3 incelendiğinde YB'nin, OA tarafından istatistiksel olarak anlamlı düzeyde etkilenmediği saptanmış (std.beta:-0.044, p:0.811) ve H3 hipotezi reddedilmiştir. ÜYSFD'nin ise OA tarafından pozitif yönde istatistiksel olarak anlamlı şekilde yordandığı saptanmış (std.beta:0.844, p<0.001) ve H1 hipotezi kabul edilmiştir. YB'nin ÜYSFD tarafından pozitif yönde istatistiksel olarak anlamlı şekilde yordandığı saptanmıştır (std.beta:0.644, $\mathrm{p}<0.001$ ). Bu bağlamda $\mathrm{H} 2$ hipotezi kabul edilmiştir.

Tablo 4.

Standartlaştırılmış Etki Büyüklükleri

\begin{tabular}{lllllllll}
\hline \multirow{2}{*}{$\begin{array}{l}\text { Tahmin } \\
\text { edilen }\end{array}$} & \multirow{2}{*}{$\begin{array}{l}\text { Tahmin } \\
\text { eden }\end{array}$} & \multirow{2}{*}{ R2adj } & \multicolumn{6}{c}{ Standartlaştırılmış tahminler } \\
\cline { 4 - 10 } & & & Doğrudan & \multicolumn{3}{c}{ Dolaylı } & Toplam \\
\cline { 4 - 10 } & & Beta & $\mathrm{p}$ & Beta & $\mathrm{p}$ & Beta & $\mathrm{p}$ \\
\hline YB & OA & \multirow{2}{*}{0.37} & -0.04 & 0.811 & 0.54 & $<0.001^{* *}$ & 0.50 & $<0.001^{* *}$ \\
\multirow{2}{*}{ ÜYSFD } & ÜYSFD & OA & 0.64 & $<0.001^{* *}$ & - & - & 0.64 & $<0.001^{* *}$ \\
\hline
\end{tabular}

Tablo 4'e göre ÜYSFD'nin YB üzerindeki doğrudan etkisi istatistiksel olarak anlamlı bulunurken $(d=0.64 ; p<0.001), O A^{\prime} n ı$ YB üzerindeki doğrudan etkisinin anlamsız olduğu saptanmıştır $(d=-0.04$; $p>0.001$ ). Bir başka deyişle YB'nin \%37'lik kısmının OA ve ÜYSFD tarafından açıklandığı görülmektedir. $O A^{\prime}$ nın ÜYSFD aracılığıyla YB üzerindeki dolaylı etkisi ise istatistiksel olarak anlamlı bulunmuştur (std.beta:0.54, p<0.001). OA'nın ÜYSFD üzerindeki doğrudan etkisi de istatistiksel olarak anlamlı bulunmuştur $(p<0.001)$. Toplam etki açısından YB'nin en baskın yordayıcısının 0.64 ile ÜYSFD olduğu, bunu 0.50 etkiyle $O A^{\prime}$ nın takip ettiği saptanmıştır.

\section{Tartışma ve Sonuç}

Üstbilişsel yazma stratejileri farkındalığı ve okuma alışkanlığının yazma becerileri üzerindeki etkisinin sınandığı bu çalışmada, oluşturulan hipotezler yapısal eşitlik modellemesiyle incelenmiştir. Bu bağlamda YB'nin, OA tarafından istatistiksel olarak anlamlı biçimde yordanmadığı saptanmış (std.beta:$0.044, p: 0.811$ ) ve $\mathrm{H} 3$ hipotezi reddedilmiştir. ÜYSFD'nin OA (std.beta:0.844, $\mathrm{p}<0.001$ ); YB'nin de ÜYSFD (std.beta:0.644, p<0.001) tarafından olumlu yönde istatistiksel olarak anlamlı biçimde yordandığı bulgulanmıştır. Bu bağlamda H1 ve H2 hipotezleri kabul edilmiştir. Öte yandan, OA'nın YB'ye ait varyansın \%21.2'sini; OA'nın ÜYSFD'ye ait varyansın \%61.9'unu ve ÜYSFD'nin YB'ye ait varyansın \%34.4'ünü açıklayabildiği sonucuna ulaşılmıştır.

Araştırmanın standartlaştırılmış etki büyüklükleri incelendiğinde, ÜYSFD’nin YB üzerindeki doğrudan etkisi istatistiksel olarak anlamlı $(p<0.001)$; $O A^{\prime} n ı n$ YB üzerindeki doğrudan etkisinin ise anlamsız olduğu saptanmıştır (p:0.811). Buna karşın OA'nın ÜYSFD aracılığıyla YB üzerindeki dolaylı etkisi istatistiksel olarak anlamlı bulunmuştur (std.beta:0.54, $p<0.001$ ). Toplam etki açısından YB'nin en baskın yordayıcısının 0.64 ile ÜYSFD olduğu belirlenmiştir. Araştırmadan elde edilen bir diğer sonuç ise, $O A^{\prime} n ı n$ ÜYSFD üzerindeki doğrudan etkisinin olumlu yönde istatistiksel olarak anlamlı $(p<0.001)$ olduğu yönündedir.

Araştırmada pearson korelasyon analizi sonucunda; OA ile ÜYSFD arasında olumlu yönde 0.789; OA ile YB arasında olumlu yönde 0.469 ve ÜYSFD ile YB arasında olumlu yönde 0.592 düzeyinde istatistiksel olarak anlamlı ilişkiler olduğu saptanmıştır. $O A^{\prime}$ ’nı $Y B$ üzerindeki doğrudan etkisinin istatiksel olarak anlamsız olması OA ile YB arasındaki görece düşük ilişkiden kaynaklı olabilir.

Araştırmadan elde edilen sonuçlar genel olarak değerlendirildiğinde, ÜYSFD ve OA'nın YB üzerinde doğrudan ve dolaylı olarak önemli etkilerinin olduğu görülmektedir. Ayrıca OA'nın ÜYSFD üzerindeki toplam $0.84^{\prime} \mid$ lük ve ÜYSFD'nin de YB üzerindeki toplam 0.64 'lük etkisi göz önüne alındığında $O A^{\prime}$ nın YB üzerindeki etkisinde ÜYSFD'nin aracı rol oynadığı söylenebilir.

Yazma ile okuma birbirini destekleyen ilişkili becerilerdir (Carson, 1990; Kush, Marley ve Brookhart, 2005). Shanahan (2006) bu durumu; uzun süreli bellek, fonolojik farkındalık ve anlambilim bilgisi gibi bilişsel becerilerdeki gelişimin hem okuma hem de yazma başarımlarını olumlu yönde 
etkilemesine bağlamaktadır. Alanyazın incelendiğinde Akkaya ve İşçi (2018) tarafından yapılan çalışmada iyi bir okur olma ve okuma tutum düzeyi ile yazılı anlatım ders başarısı arasında doğrudan yüksek düzeyde bir ilişki olmadığı bulgulanmıştır. Eroğlu (2013), öğretmen adaylarının okuma alışkanlığı ve doğru yazma becerileri arasındaki ilişkiyi incelediği çalışmasında, ilişkinin olumlu yönlü olduğu fakat aralarındaki korelasyon katsayılarının çok yüksek olmadığı sonucuna ulaşmıştır. Buna karşın Baş (2012) okumaya ilişkin tutum ile yazma eğilimi arasında; Kartal (2017) ise okuma alışkanlığı ile öyküleyici yazma becerileri arasında olumlu yönde güçlü bir ilişki olduğunu bulgulamıştır. Bell (1998) ve Hafiz ve Tudor (1989) ise geniş okumalar yapmanın yazılı anlatım becerilerini geliştirmedeki önemine vurgu yapmıştır. Benzer bir biçimde öğretmenler de yazma becerilerinin geliştirmesinde okuma alışkanlığının önemli olduğu görüşündedir (Tok ve Ünlü, 2014). Zainal ve Husin (2011) tarafından yapılan çalışmada okumanın sözcük bilgisini geliştirme, fikirleri organize etme ve konuya çeşitli açılardan yaklaşabilme gibi yönlerden yazma becerisine olumlu etki ettiği belirtilmiştir. Bu bulgular ve görüşler okuma ile yazma arasında bir ilişki olduğunu ortaya koymaktadır. Ancak alanyazındaki bu çalışmalardan elde edilen farklı ilişki düzeyleri, okuma ile yazma arasındaki ilişkinin ne düzeyde olduğu konusunda tartışmalara yol açmaktadır. Nitekim bu araştırma için oluşturulan modelde okuma alışkanlığının yazma başarımını doğrudan değil de dolaylı bir biçimde etkilediği görülmektedir. Öte yandan okuma alışkanlığının yazma becerilerini dolaylı olarak etkilemesinin aksine okuduğunu anlamayı doğrudan etkilemesi beklenir. Buna karşın, Yıldız ve Akyol (2011) tarafından yapılan çalışmada öğrencilerin okuma alışkanlıklarının okuduğunu anlama başarısına da doğrudan etkisinin olmadığı belirlenmiştir. $\mathrm{Bu}$ bağlamda okumanın yazma başarımını etkilemesinde aracı rolünü üstlenecek başka değişkenlere ihtiyaç olduğu söylenebilir. Bu durumda yazma başarımını olumlu yönde etkileyen değişkenler üzerinde okuma alışkanlığının etkisini belirlemenin yazma becerilerinin geliştirilmesi açısından daha önemli olabileceği düşünülmektedir. Öte yandan okuma ve yazma ne kadar birbirini destekleyen ilişkili beceriler olsa da farklı kavramsal temellere sahip iki ayrı beceridir (Fitzgerald ve Shanahan, 2000). Alanyazında yer alan "yetkin okur-yetkin yazar, yetkin olmayan okur-yetkin olmayan yazar, yetkin okuryetkin olmayan yazar, yetkin yazar-yetkin olmayan okur" (Stotsky, 1983; Tierney, 1983) biçimindeki sınıflandırmalar okuma ve yazma başarımlarının her zaman birbirleriyle koşutluk içerisinde olmayacağını göstermektedir. Fitzgerald ve Shanahan (2000), okuma ve yazma arasındaki teorik bağlantıyı kabul etmelerine rağmen, bu iki beceri arasındaki kavramsal ve deneysel farklılığı korumanın önemini belirtmişlerdir.

Strateji bir işteki başarıyı ve verimi artırmak için kullanılır. Strateji kullanarak bir iş veya eylem daha kolay ya da daha hızlı yapılabilir (Topuzkanamış, 2014b). Bilişsel yazma stratejileri zihinde yer alan bilgilerin yazıya aktarılmasında ve yazma ilgili sorunların çözümlenmesinde; üstbilişsel yazma stratejileri ise bu sürecin denetiminde işe koşulan stratejilerdir (Collins, 2000). Genel anlamda yazma stratejileri ise, yazma sürecinin sonunda nitelikli bir ürün elde etmek amacıyla yürütülen işlemlerdir (Graham ve Harris, 2005). Alanyazına bakıldığında yazma stratejileri öğretiminin veya yazma stratejilerini etkili bir biçimde kullanmanın yazma becerilerini olumlu yönde etkilediğine (Byrer, 1986; Mastan ve Maarof, 2014; Sommers, 1980; Topuzkanamış, 2014a) ve yorum gücünü artırdığına (Kieft, Rijlaarsdam ve Bergh, 2006) yönelik çalışmalar olduğu görülmektedir. Öte yandan üstbilişsel stratejilere sahip bireyler daha özerk ve bağımsız; öğrenme sürecinde ise planlama, izleme ve değerlendirme konusunda daha yetenekli olurlar (Lv ve Chen, 2010). Nitekim alanyazında üstbilişsel strateji/bilgi ile yazma becerisi üzerine yapılan çalışmalarda (Lv ve Chen, 2010; Ong ve Zhang, 2013; Rahimi ve Karbalaei, 2016; Tabrizi ve Rajaee, 2016; Yanyan, 2010) üstbilişsel yazma stratejilerinin üstbilişsel farkındalığı artırdığı belirlenmiş; artan üstbilişsel farkındalığın da öğrencilerin yazma becerilerinin geliştirdiği, yazma becerilerinin gelişmesini çeşitli yönlerden destekleyen yazma tutumu, üst düzey düşünme, yoğunlaşma gibi becerilerini olumlu yönde etkilediği saptanmıştır. Araştırmadan elde edilen YB'nin ÜYSFD (std.beta:0.644, p<0.001) tarafından olumlu yönde istatistiksel olarak anlamlı biçimde yordandığı bulgusu ile yukarıda söz edilen çalışmaların sonuçları örtüşmektedir.

Okuma alışkanlığı; düşünme, problem çözme, neden-sonuç ilişkisi kurma, olaylar arası anlamlı bağıntılar oluşturma ve yaratıcılık gibi becerilerin gelişiminde oldukça önemlidir (Tanju, 2010). Bu beceriler ise üstbilişsel farkındalık için birer ön koşul niteliğindedir. Nitekim bu çalışmadan elde edilen OA ve ÜYSFD arasındaki anlamlı ve görece yüksek düzey ilişki bu görüşü desteklemektedir. Aydın ve 
Bağcı Ayrancı (2018) tarafından yapılan çalışmadan elde edilen okuma alışkanlığı ile üstbilişsel yazma stratejileri farkındalığı arasında olumlu yönde anlamlı bir ilişkinin olduğu bulgusu bu çalışmanın bulgularıyla örtüşmektedir.

Araştırmadan elde edilen bulgular, okuma alışkanlığının üstbilişsel yazma stratejileri farkındalı̆̆ı üzerinde doğrudan ve yazma başarımı üzerinde ise dolaylı olarak etkili olduğunu göstermektedir. Bu bulgular hem üstbilişsel yazma stratejileri farkındalı̆̆ını hem de yazma başarımını artırmada okumanın önemini belirginleştirmektedir. Bu bağlamda öğrenciler henüz erken yaşlarda onların hoşlanabileceği türden kitaplarla tanıştırılmalı ve böylelikle onların okumaya yönelik olumlu tutum geliştirmeleri sağlanmalıdır. Okumaya yönelik olumlu tutum geliştirme sürecinde öğretmenlere ve ebeveynlere önemli görevler düşmektedir. Okulda ve evde okuma saatleri düzenlenmeli, okunan kitaplara ilişkin öğrencilere tartışma ortamları hazırlanmalıdır. Ebeveynlerin öğrencilerle birlikte okuma sürecine dahil edilmesi öğrencilere rol model olunması açısından da önemlidir. Araştırmadan elde edilen diğer bir bulgu üstbilişsel yazma stratejileri farkındalığının yazma başarımı üzerinde doğrudan etkili olduğu yönündedir. Üstbilişsel yazma stratejileri farkındalığının yazma başarımı üzerindeki bu yordayıcı rolü dikkate alındığında öğretmenlerin öncelikle öğrencilerin yazma sürecinde işe koşulabileceği stratejilere yönelik eğitim planı oluşturması ve süreç içerisinde bu strateji kullanımlarının denetimini yaparak öğrencilere dönütler vermesi gerekir. Strateji eğitimine yönelik düzenlenecek bu planlamanın öğrencilerin üstbilişsel yazma stratejileri farkındalığııın artırılmasına katkı sağlayacağı düşünülmektedir.

\section{Araştırma ve Yayın Etiği}

Bu çalışmada "Yükseköğretim Kurumları Bilimsel Araştırma ve Yayın Etiği Yönergesi" kapsamında uyulması belirtilen tüm kurallara uyulmuştur. Yönergenin ikinci bölümü olan "Bilimsel Araştırma ve Yayın Etiğine Aykırı Eylemler" başlığı altında belirtilen eylemlerden hiçbiri gerçekleştirilmemiştir.

\section{Etik Kurul Izni}

Kurul adı = Bolu Abant İzzet Baysal Üniversitesi Sosyal Bilimlerde İnsan Araştırmaları Etik Kurulu Karar tarihi $=01.02 .2021$

Belge sayı numarası $=2021 / 08,2021 / 01$

\section{Yazarların Katkı Oranı}

Bu makale tek yazar tarafından hazırlanmıştır.

\section{Çıkar Çatışması}

Bu makalede çıkar çatışması oluşturabilecek herhangi bir durum ya da ilişki yoktur.

\section{Kaynaklar}

Adler, R., Rosenfeld, L. ve Proctor, R. (2001). Interplay: The process of interpersonal communicating. (2. bs.), Forth Worth, TX: Hrourt.

Ak Mert, Ö. (2007). Jean Piaget düşüncesinde psikolojik yapılar. Yayımlanmamış yüksek lisans tezi, Gazi Üniversitesi, Ankara.

Akın, E. (2016). Ortaokul öğrencilerinin okuma alışkanlığı ve yazma tutumları ile Türkçe dersi akademik başarıları arasındaki ilişkinin incelenmesi. Akademik Bakış Dergisi, 54, 469-483.

Akkaya, N. ve Isççi, C. (2018). Eğitim fakültesi öğrencilerinin okumaya yönelik tutumları ile yazıı ınlatım ders başarısı arasındaki ilişki. Uluslararası Türkçe Edebiyat Kültür Eğitim Dergisi, 7(2), 11611171.

Alberth. (2018). Use of facebook, students' intrinsic motivation to study writing, writing self-efficacy and writing performance. Technology, Pedagogy and Education, 28(1), 21-36.

Applebee, A. (1984). Writing and reasoning. Review of Educational Research, 54, 577-596.

Arıcı, M. A. ve Dölek, O. (2020). Ortaokul öğrencilerinin yazma özyeterlik algı düzeyleri ile yazma başarımları arasındaki ilişki. Ana Dili Eğitimi Dergisi, 8(4), 1204-1217. 
Arslan, Y., Çelik, Z. ve Çelik, E. (2009). Üniversite öğrencilerinin okuma alışkanlığına yönelik tutumlarının belirlenmesi. PÜ Eğitim Fakültesi Dergisi, 26, 113-124.

Aybek, B. ve Aslan, S. (2016). Öğretmen adaylarının üstbilişsel okuma stratejilerinin çeşitli değişkenler açısından incelenmesi. International Journal of Social Science, 49, 533-546

Aydın, G. ve Bağcı Ayrancı, B. (2018). Metacognitive writing skills strategy awareness of secondary school students. Modern Journal of Language Teaching Methods, 8(5), 435-445.

Aydın, İ. S., İnnalı, H. Ö. ve Uyumaz, G. (2017). Üstbilişsel yazma stratejileri farkındalık ölçeği'nin geliştirilmesi ve psikometrik özelliklerinin belirlenmesi. Electronic Turkish Studies, 12(25), 169192.

Bai, B. (2015). The effects of strategy -based writing instruction in Singapore primary schools. System, 53, 96-106.

Baki, Y. (2017). Ortaokul öğrencilerinin okumaya ilişkin kaygı ve tutumlarının okuma alışkanlığı üzerindeki etkisi: Bir yapısal eşitlik modellemesi. Eğitim ve Bilim, 42(191), 371-395.

Balcı, A., Uyar, Y. ve Büyükikiz, K. K. (2012). İlköğretim 6. sınıf öğrencilerinin okuma alışkanlıkları, kütüphane kullanma sıklıkları ve okumaya yönelik tutumlarının incelenmesi. Turkish Studies, 7(4), 965-985.

Bamberger, R. (1990). Okuma alışkanlığını geliştirme. (B. Çapar, çev.). Ankara: Kültür Bakanlığı.

Bashir, I. ve Mattoo, N. H. (2012). A Study on study habits and academic performance among adolescents (14-19) years. International Journal of Social Science Tomorrow, 1(5), 1-5.

Baş, G. (2012). Correlation between elementary students' reading attitudes and their writing dispositions. International Journal of Global Education, 1(2), 1-6.

Baş, G. ve Şahin, C. (2012). Illköğretim 6. 7. ve 8. sınıf öğrencilerinin okuma tutumları ve yazma eğilimleri ile Türkçe dersindeki akademik başarıları arasındaki ilişki. Turkish Studies, 7(3), 555-572.

Bayat, N. (2014). Sürece dayalı yazma yaklaşımının yazma başarısı ve kaygısı üstündeki etkisi. Kuram ve Uygulamada Eğitim Bilimleri, 14(3), 1123-1141.

Belet, Ş. D. ve Yaşar, Ş. (2007). Öğrenme stratejilerinin okuduğunu anlama ve yazma becerileri ile Türkçe dersine ilişkin tutumlara etkisi. Eğitimde Kuram ve Uygulama, 3(1), 69-86.

Bell, T. (1998). Extensive reading: Why? and how. The Internet TESL Journal, 4(12), 1-6.

Büyüköztürk, Ş., Kılıç Çakmak, E., Akgün, Ö., E., Karadeniz, Ş. ve Demirel F. (2016). Bilimsel araştırma yöntemleri. (21. bs.). Ankara: Pegem Akademi.

Byrer, B. R. (1986). The effect of a pre-writing learning strategy on the growth of syntactic maturity in written expression of college freshmen with learning disabilities. Unpublished doctoral thesis. West Virginia University.

Carson, J. (1990). Reading-writing connections: Toward a description for second language learners. Kroll, B. (Ed.), Second language writing: Research insights for the classroom. New York: Cambridge University Press.

Chalk, J. C., Hagan-Burke, S. ve Burke, M. D. (2005). The effects of self-regulated strategy development on the writing process for high school students with learning disabilities. Learning Disability Quarterly, 28(1), 75-87.

Chari, M., Samavi, A. ve Kordestani, D. (2010). Investigating psychometric characteristics of metacognitive reading strategies scale among Iranian high-school students. Psychiatry Studies, 6(1), 1-22.

Collins, J. L. (2000). Review of key concepts in strategic reading and writing instruction. J. L. Collins (Ed.). Cheektowaga-Sloan handbook of practical reading and writing strategies içinde (pp. 5$10)$.

Conti, G. (2004). Metacognitive enhancement and error correction. Unpublished doctoral dissertation, University of Reading, Reading, UK.

Creswell, J. W. (2016). Araştırma deseni: Nitel, nicel ve karma yöntem ve yaklaşımları. S. B. Demir (Çev. Ed.). (2. bs.). Ankara: Eğiten Kitap.

Çakıroğlu, A. (2007). Üstbilişsel strateji kullanımının okuduğunu anlama düzeyi düşük öğrencilerde erişi artırımına etkisi. Yayınlanmamış doktora tezi, Gazi Üniversitesi, Ankara. 
De Silva, R. (2015). Writing strategy instruction: Its impact on writing in a second language for academic purposes. Language Teaching Research, 19(3), 301-323.

Demir, T. (2013). Yazma becerisine yönelik kazanımların ortaokulda gerçekleşme düzeyi. Okuma Yazma Eğitimi Araştırmaları, 1(1), 45-56.

Doğan, A. (2013). Üstbiliş ve üstbilişe dayalı öğretim. Middle Eastern and African Journal of Educational Research, 3(6), 6-20.

Dolunay, K. S. ve Dölek, O. (2018). Ortaokul öğrencilerinin cümle bağlayıcıları kullanımlarına ilişkin görünümler. IKSAD 2. Uluslararası Sosyal Bilimler Kongresi Tam Metin Kitabı içinde, (ss. 541549). Ankara: Iksad Yayınevi.

Dölek, O. ve Hamzadayı, E. (2016). Akran etkileşimine dayalı yazma etkinliklerinin 7. sınıf öğrencilerinin yazılı anlatım becerileri üzerindeki etkisi. Turkish Studies, 11(3), 965-980.

Dölek, O. ve Hamzadayı, E. (2018). Comparison of writing skills of students of different socioeconomic status. International Journal of Progressive Education, 14(6), 117-131.

Eroğlu, Z. D. (2013). Öğretmen adaylarının okuma alışkanlıkları ile doğru yazma becerileri arasındaki ilişki. Turkish Studies, 8(9), 1441-1453.

Fitzgerald, J. ve Shanahan, T. (2000). Reading and writing relations and their development. Educational Psychologist, 35, 39-50.

Flavell, J. H. (1979). Metacognition and cognitive monitoring: A new area of cognitive-developmental inquiry. American psychologist, 34(10), 906-911.

Gelen, i. (2003). Bilişsel farkındalık stratejilerinin Türkçe dersine ilişkin tutum, okuduğunu anlama ve kalıcılığa etkisi. Yayınlanmamış doktora tezi, Çukurova Üniversitesi, Adana.

Gönen, M., Öncü, E., Ç. ve Işıtan, S. (2004). İlköğretim 5., 6. ve 7. sınıf öğrencilerinin okuma alışkanlıklarının incelenmesi. Millî Eğitim, 164, 7-35.

Graham, S. (2006). Writing. P. Alexander ve P. Winne (Ed.), Handbook of educational psychology (s. 457-478) içinde. Mahwah, NJ: Erlbaum.

Graham, S. ve Harris, K. R. (2005). Writing better effective strategies for teaching students with learning difficulties. Baltimore: Paul H. Brookes Publishing.

Grellet, F. (1981). Devoloping reading skills. New York: Cambridge University Press.

Gürefe, N. (2015). Illköğretim öğrencilerinin üstbilişsel farkındalıklarının bazı değişkenlere göre incelenmesi. Uluslar Arası Eğitim Bilimleri Dergisi, 2(5), 237-246.

Hafiz, F. M. ve Tudor, I. (1989). Extensive reading and the development of language skills. ELT Journal, 43(1), 4-13.

Harmer, J. (2007). How to teach writing. Malaysia: Pearson Education Limited.

Huerta, M., Goodson, P., Beigi, M. ve Chlup, D. (2017). Graduate students as academic writers: writing anxiety, self-efficacy and emotional intelligence. Higher Education Research \& Development, 36(4), 716-729.

Kana, F. (2014). Ortaokul öğrencilerinin üstbiliş okuma stratejileri farkındalık düzeyleri. Erzincan Üniversitesi Eğitim Fakültesi Dergisi, 16(1), 100-120.

Kapucu, M. S. ve Öksüz, R. (2015). Ortaokul öğrencilerinin üstbilişsel farkındalıklarının incelenmesi. Eğitim ve insani Bilimler Dergisi, 6(12), 5-28.

Kartal, Z. (2017). The relationship between students' reading habit and their narrative writing ability. The Department of English Educatıon Faculty Of Educational Sciencies Syarıf Hıdayatullah State Islamic University, Tangerang.

Kaya, B. ve Ateş, S. (2016). Üstbilişsel beceri odaklı yazma süreçlerinin dördüncü sınıf öğrencilerinin hikâye yazma becerisine etkisi. Eğitim ve Bilim, 41(187), 137-164.

Kieft, M., Rijlaarsdam, G. ve Bergh, H. B. (2006). Writing as a learning tool: Testing the role of students' writing strategies. European Journal of Psychology of Education, 11(1), 17-34.

Konedralı, G. ve Özder, H. (2007). Yazılı anlatım becerisinin geliştirilmesinde "Sözlü anlatım destekli ön çalışma" yönteminin etkililiği. Doğu Akdeniz Üniversitesi 1. Uluslararası Türkçe Eğitimi ve Öğretimi Sempozyumu.

Kuruyer, H. G. ve Özsoy, G. (2016). İyi ve zayıf okuyucuların üst bilişsel okuma becerilerinin incelenmesi: Bir durum çalışması. Kastamonu Eğitim Fakültesi Dergisi, 24(2), 771-778. 
Kush, J. C., Marley, W. W. ve Brookhart, S. M. (2005). The temporal-interactive influence of reading on achievement and reading attitude. Educational Research and Evaluation, 11(1), 29-44.

Leung, C. Y. (2002). Extensive reading and language learning: A diary study of a beginning learner of Japanese. Reading in a foreign language, 14(1), 66-81.

Lv, F. ve Chen, H. (2010). A study of metacognitive-strategies-based writing instruction for vocational college students. English Language Teaching, 3(3), 136-144.

Mastan, M. E. ve Maarof, N. (2014). ESL learners' self-efficacy beliefs and strategy use in expository writing. Procedia-Social and Behavioral Sciences, 116, 2360-2363.

Mokhtari, K. ve Reichard, C. A. (2002). Assessing students' metacognitive awareness of reading strategies. Journal of Educational Psychology, 94(2), 249-259.

Monet, B. (2003). Think literacy: Cross-curricular approaches, grades 7-12. Ontario Secondary School Literacy Course Ltd.

Ong, J. ve Zhang, L. J. (2013). Effects of the manipulation of cognitive processes on EFL writers' text quality. TESOL Quarterly, 47(2), 375-398.

Orhan, R. (2017). Alışkanlık. Kırıkkale Üniversitesi Sosyal Bilimler Dergisi, 7(2), 301-316.

Owo, W. J. ve Ikwut, E. F. (2015). Relationship between metacognition, attitude and academic achievement of secondary school chemistry students in Port Harcourt, Rivers State. IOSR Journal of Research \& Method in Education (IOSR-JRME), 5(6), 6-12.

Oxford, R. (1990). Language learning strategies. Boston: Heinle and Heinle Publishers.

Özdemir, O., Özdemir, P. G., Kadak, M. T. ve Nasıroğlu, S. (2012). Kişilik gelişimi. Psikiyatride Güncel Yaklaşımlar, 4(4), 566-589.

Özer, Ö. Y. ve Doğan, B. (2013). Illköğretim 8. sınıf öğrencilerinin okuma becerisinin kestirilmesinde etkili olan değişkenlerin belirlenmesi. International Journal of Social Science, 6(4), 667-680.

Özonat, Z. (2015). Sekizinci sınıf öğrencilerinin yazma öz yeterlik algıları. Erzincan Üniversitesi Sosyal Bilimler Enstitüsü Dergisi, 9(2), 207-220.

Öztürk, B. K. (2012). İlköğretim ikinci kademe öğrencilerinin yazma kaygılarının çeşitli değişkenler açısından incelenmesi. Çukurova Üniversitesi Sosyal Bilimler Enstitüsü Dergisi, 21(2), 59-72.

Pour-Mohammadi, M., Abidin, M. J. Z. ve Fong, C. L. (2012). The effect of process writing practice on the writing quality of form one students: A case study. Asian Social Science, 8(3), 88-99.

Pressley, M. (2002). Reading instruction that works: The case for balanced teaching. (2. bs.). New York: Guilford Press.

Rahimi,F. ve Karbalaei, A. (2016). The role of metacognitive strategies training on developing writing skill among Iranian EFL learners. Journal of Current Research in Science, 1, 327-341.

Rao, Z. (2007). Training in brainstorming and developing writing skills. ELT Journal, 61(2), 100-106.

Shanahan, T. (2006). Relations among oral language, reading, and writing development. C. MacArthur, S. Graham ve J. Fitzgerald (Ed.). Handbook of writing research (pp. 171-183) içinde. New York: Guilford Press.

Smith, E., E. ve Kosslyn, S. M. (2017). Bilişsel psikoloji: Zihin ve beyin. M. Şahin, (Çev. Ed.). Ankara: Nobel Yayıncilık.

Smyth, J. (1998). Written emotional expression: Effect sizes, outcome types, and moderating variables. Journal of Consulting and Clinical Psychology, 66, 174-184.

Sommers, N. (1980). Revision strategies of student writers and experienced adult writers. College composition and communication, 31(4), 378-388.

Stotsky, S. (1983). Research on reading/writing relationships: A synthesis and suggested directions. Language Arts, 60, 627-643.

Tabrizi, N., A. R. ve Rajaee, M. (2016). The effect of metacognitive and cognitive writing strategies on Iranian elementary learners' writing achievement. International Journal of Learning and Development, 6(3), 216-229.

Tanju, E. H. (2010). Çocuklarda kitap okuma alışkanlığı'na genel bir bakış. Sosyal Politika Çalışmaları Dergisi, 6(22), 30-39.

Tierney, R. J. (1983). Analyzing composing behavior: Planning, aligning, revising. Paper presented at the 33rd annual National Reading Conference, Austin, TX. 
Tok, M. ve Ünlü, S. (2014). Yazma becerisi sorunlarının ilkokul, ortaokul ve lise öğretmenlerinin görüşleri doğrultusunda karşılaştırılmalı olarak değerlendirilmesi. Elektronik Sosyal Bilimler Dergisi, 13(50), 73-95.

Tok, M., Küçük, B. ve Kırmacı, Ö. (2015). Ortaokul kitap okuma alışkanlığı ölçeği: geçerlik güvenirlik çalışması. Eğitimde Kuram ve Uygulama, 11(2), 694-716.

Topuzkanamış, E. (2014a). Yazma stratejileri öğretiminin Türkçe öğretmenliği birinci sınıf öğrencilerinin yazma başarısına etkisi. Uluslararası Türkçe Edebiyat Kültür Eğitim (Teke) Dergisi, 3(2), 274290.

Topuzkanamış, E. (2014b). Yazma stratejileri öğretiminin Türkçe öğretmenliği birinci sınıf öğrencilerinin yazma başarısına etkisi. Yayımlanmamış doktora tezi, Gazi Üniversitesi, Ankara.

Westwood, P. (2008). What Teachers need to know about reading and writing difficulties. Australia: ACER Press.

Yanyan, Z. (2010). Investigating the role of metacognitive knowledge in English writing. HKBU Papers in Applied Language Studies, 14, 25-46.

Yıldız, M. ve Akyol, H. (2011). ilköğretim 5. sınıf öğrencilerinin okuduğunu anlama, okuma motivasyonu ve okuma alışkanlıkları arasındaki ilişki. Gazi Eğitim Fakültesi Dergisi, 31(3), 793-815.

Yılmaz, Z. A. (2006). Sınıf öğretmeni adaylarının okuma alışkanlığı. Ilköğretim Online. 5(1), 1-6.

Yüksel, G. (2013). Bilişsel öğrenme kuramı. S. Büyükalan Filiz (Ed.), Öğrenme öğretme kuram ve yaklaşımları içinde (ss. 46-72). (2. bs.). Ankara: Pegem Akademi.

Zainal, Z. ve Husin, S. H. B. M. (2011). A study on the effects of reading on writing performance among faculty of civil engineering students. Journal of Science and Mathematics Education, 1-8.

Zulkiply, N. (2009). Metacognition and its relationship with students' academic performance. The International Journal of Learning, 15(11), 97-106.

\section{Introduction}

\section{Extended Abstract}

Writing is a versatile tool that can be used to convey thoughts, ideas, plans, emotions, impressions, and dreams to another person (Dolunay \& Dölek, 2018, p. 575; Graham, 2006). Adler et al. (2001) claim that individuals spend $45 \%$ of their communication time on listening, $30 \%$ on speaking, $16 \%$ on reading, and $9 \%$ on writing. Based on these rates, it can be noted that writing is the least used skill among the other basic language skills. However, along with the developing technology, people's need to write also increases. The literature review has shown that there are studies investigating the effectiveness of various methods, techniques, and strategies to improve writing skill (Alberth, 2018; Bayat, 2014; Dölek \& Hamzadayı, 2016; Rao, 2007) and those examining writing skill in terms of affective qualities (Arıcı \& Dölek, 2020; Huerta et al., 2017; Özonat, 2015). It is also reported that writing skill is not at the desired level among middle school students (Dölek \& Hamzadayı, 2018). For this reason, this study focused on reading habit and metacognitive writing strategies awareness, which are predicted to be effective on writing skills, as well as methods, techniques, strategies, and affective qualities. Based on this purpose, first, the concepts of reading habit and metacognitive writing strategies awareness were explained.

Reading habit can be defined as one's doing reading activity continuously and regularly throughout their life as a result of the perception of reading as a pleasure and necessity (Gönen, Öncü, \& Işıtan, 2004, p. 8). Reading habit continuously develops the cognitive and affective aspects of the individual and plays an active role in raising them as useful persons to society. On the other hand, Bashir and Mattoo (2012) state that reading habit also affects students' academic success.

Metacognitive writing strategies awareness can be defined as an individual's awareness about the functions of the strategies that can be employed before, during, and after writing stages and their own cognitive skills related to writing strategies. An individual who has cognitive awareness, first of all, becomes motivated for the subject they will learn, concentrates their attention, and develops attitude. Thus, they can control their knowledge and thoughts using cognitive awareness. Subsequently, they evaluate what they know and what they should know. They see where they are, then plan what they will do. They evaluate the plan, correct it and try again. Afterward, they become 
aware of how much they have learned, how they have learned, which ways of thinking they have followed and develop this behavior (Gelen, 2003). A person with high a level of metacognitive writing strategies awareness is expected to control themselves and their writing process. Kaya and Ateş (2016) state that individuals with high levels of metacognitive writing strategies awareness should ask questions to themselves about the type of the text, the time required to write, plan of the article, and review of the text in the writing process.

\section{Method}

This study designed in the relational scanning model was conducted to determine the middle school students' reading habit and metacognitive writing strategies awareness on their writing achievement, to explain how these variables predicted each other, and to determine the levels of their explanation rates. Its sample consisted of 100 eighth-grade students in a middle school in the province of Gaziantep in Turkey. Of the students in the study group, $51 \%(n=51)$ were male and $49 \%(n=49)$ were female. Data were collected using the Metacognitive Writing Strategies Awareness Scale, the Middle School Reading Habits Scale, written expression texts, and the Composition Evaluation Scale that was used to evaluate these texts.

\section{Result and Discussion}

Hypotheses formed in this study were examined using structural equation modeling. The study found that WS was not statistically significantly predicted by RH (std. beta $=-0.044, \mathrm{p}: 0.811$ ) and the H3 hypothesis was rejected. RH positively and significantly predicted MWSA (std.beta:0.844, $p<0.001$ ) and MWSA positively and significantly predicted WS (std. beta $=0.644, \mathrm{p}<0.001$ ). In this context, $\mathrm{H} 1$ and $\mathrm{H} 2$ hypotheses were accepted. However, it was found that RH explained $21.2 \%$ of the variance of WS, RH explained $61.9 \%$ of the variance of MWSA, and MWSA explained $34.4 \%$ of the variance of WS.

Analysis of the standardized effect sizes of the study showed that the direct effect of MWSA on WS was statistically significant $(p<0.001)$ and that of RH on WS was not significant $(p: 0.811)$. However, the indirect effect of RH on WS through MWSA was found to be statistically significant (std.beta:0.54, p<0.001). When the results were examined in terms of the total effect, the most dominant predictor of WS was MWSA with 0.64 . Another result obtained from the study was that the direct effect of RH on MWSA was positively and statistically significant $(p<0.001)$.

According to Pearson's correlation analysis, there were positive and statistically significant relationships between RH and MWSA (0.789), RH and WS (0.469), and MWSA and WS. The statistically insignificant direct effect of RH on WS may be due to the relatively low relationship between RH and WS. When the results obtained from the study were generally evaluated, it was found that MWSA and $\mathrm{RH}$ had a significant direct and indirect effect on WS. Also, considering the 0.84 total effects of $\mathrm{RH}$ on MWSA and 0.64 total effects of MWSA on WS, it can be said that MWSA played mediating role in the effect of RH on WS. Accordingly, students should be introduced to the kind of books they may like at an early age and develop a positive attitude toward reading. Teachers and parents have important responsibilities in this process. Reading hours must be organized at school and home and both students and parents should be involved in this process in terms of being role models for students. On the other hand, considering the predictive effect of metacognitive writing strategies awareness on writing success, the fact that teachers primarily create an education plan for the strategies where students can be employed in the writing process and provide feedback to students by controlling their use of these strategies in the process can contribute to increasing students' metacognitive writing strategies awareness. 